CLINICAL STUDY

\title{
MEN1 intragenic deletions may represent the most prevalent somatic event in sporadic primary hyperparathyroidism
}

\author{
Maria Inês Alvelos ${ }^{1,2}$, João Vinagre ${ }^{1,3,4}$, Elsa Fonseca ${ }^{1,4,5}$, Eva Barbosa ${ }^{3,6}$, José Teixeira-Gomes ${ }^{1}$, \\ Manuel Sobrinho-Simões ${ }^{1,4,5}$ and Paula Soares ${ }^{1,4}$ \\ ${ }^{1}$ Institute of Molecular Pathology and Immunology of the University of Porto (IPATIMUP), 4200-465 Porto, Portugal, ${ }^{2}$ Faculty of Engineering of the \\ University of Porto (FEUP), 4200-465 Porto, Portugal, ${ }^{3}$ Institute of Biomedical Sciences Abel Salazar (ICBAS), University of Porto, $4099-003$ Porto, \\ Portugal, ${ }^{4}$ Medical Faculty of the University of Porto (FMUP), 4200-319 Porto, Portugal, ${ }^{5}$ Department of Pathology, Hospital S João, $4200-319$ Porto, \\ Portugal and ${ }^{6}$ Hospital Pedro Hispano, 4454-509 Porto, Portugal
}

(Correspondence should be addressed to P Soares who is now at IPATIMUP - Cancer Biology, Rua Dr Roberto Frias, s/n, 4200-465 Porto, Portugal; Email: psoares@ipatimup.pt)

\begin{abstract}
Objective: Primary hyperparathyroidism (pHPT) is characterised by an inappropriate over production of parathyroid hormone and it is the most frequent pathological condition of the parathyroid glands. A minority of the cases belong to familial forms, but most of them are sporadic. The genetic alterations underlying the sporadic forms of pHPT remain poorly understood. The main goal of our study is to perform the molecular characterisation of a series of sporadic pHPT cases.

Design and methods: We have studied matched blood and tumour from 24 patients with pHPT, who went to a medical appointment in Hospital Pedro Hispano. Informed consent was obtained from all individuals. The MEN1, RET and CDKN1B molecular study was carried out in the germline DNA by PCR/SSCP and direct sequencing. Parathyroid tumours were further analysed by the same methods for MEN1, CDKN1B and CTNNB1 genetic alterations. The multiplex ligation-dependent probe amplification technique enabled the evaluation of MEN1 gene deletions. Protein expression for menin, cyclin D1, parafibromin, p2 $7^{\mathrm{Kip} 1}, \beta$-catenin and Ki-67 was conducted by immunohistochemistry.

Results: The study of parathyroid tumours detected two somatic MEN1 mutations (c.249_252delGTCT and c.115_163del49bp) and revealed the presence of MEN1 intragenic deletions in 54\% (13/24) of the tumours. In RET and CDKN1B genes only previously described, non-pathogenic variants were found. Cyclin D1 protein was overexpressed in 13\% (3/24) of tumours.

Conclusions: These results suggest that MEN1 alterations, remarkably intragenic deletions, may represent the most prevalent genetic alteration in sporadic parathyroid tumours.
\end{abstract}

European Journal of Endocrinology 168 119-128

\section{Introduction}

Primary hyperparathyroidism (pHPT) represents one of the most common endocrine disorders in western populations (1). Clinically, the hallmark of pHPT is characterised by a disproportionate secretion of parathyroid hormone (PTH) that culminates in raised serum calcium causing adverse effects on many organs. Sporadic cases of pHPT are often attributed to the presence of a benign, single adenoma in $80 \%$ of the cases, to multiglandular parathyroid hyperplasia in $15-20 \%$ of cases and to parathyroid carcinoma in about 1\% (2).

Non-familial pHPT accounts for more than $95 \%$ of the cases, while the remaining cases occur in the setting of inherited disorders: multiple endocrine neoplasia type 1 or type 2 (MEN1 or MEN2) and more rarely HPT-jaw tumour (HPT-JT) syndrome, caused by germline mutations in MEN1 tumour suppressor gene, RET proto-oncogene and HRPT2 (CDC73) tumour suppressor gene $(3,4)$. Additionally, germline mutations in CDKN1B, the gene coding for the cyclin-dependent kinase inhibitor $\mathrm{p} 27^{\mathrm{Kip} 1}$, were identified in a few families bearing a MEN1-like syndrome, thus evidencing a p $27^{\text {Kip } 1}$ contribution in pHPT development (5). Therefore, the identification of CDKN1B germline mutations has defined a novel multiple endocrine neoplasia syndrome, MEN4 (OMIM No.610755) (6). This entity clinically closer to $\mathrm{pHPT}$ is characterised by parathyroid involvement and, less typically, by pituitary adenomas and other endocrine features (7). Until now, six germline CDKN1B mutations have been found in patients with a MEN1-like phenotype but were negative for MEN1 mutations (8). At variance with the wellknown genetic alterations underneath familial pHPT, the molecular alterations underlying the sporadic forms still remain poorly understood. In an attempt to 
elucidate the genetic alterations of sporadic pHPT, classical tumour suppressor genes have been investigated (e.g. TP53, RB and those encoding cyclindependent kinase inhibitors - CDKN2A, CDKN2C and CDKN2D), but evidence of somatic inactivation of these genes in parathyroid tumours was rarely found $(9,10)$.

$\beta$-Catenin is a transcription-activating protein with oncogenic potential, and a mutation-dominant effect has been hypothesised; until now, only somatic heterozygous mutations have been identified for CTNNB1 (sporadic colorectal carcinoma, hepatoblastoma) (11). Deregulated activation of the Wnt signalling pathway, through stabilising $\beta$-catenin mutations in exon 3 or inactivating APC mutations, is involved in the majority of colorectal cancer $(11,12)$. Also in primary (parathyroid tumours) and in secondary HPT (hyperplastic parathyroid glands), excessive $\beta$-catenin signalling was reported as a major alteration. Bjorklund et al. (13) demonstrated activation of the canonical pathway through excessive $\beta$-catenin signalling and the presence of a stabilising mutation in a small subset of cases. Conversely, independent studies of parathyroid adenoma series have failed to identify mutations in the $\beta$-catenin gene, CTNNB1 (14).

To date, two genes have established roles in the development of sporadic parathyroid tumours: MEN1 and cyclin D1 (CCND1), both located at chromosome 11 (11q13). MEN1 tumour suppressor gene, which was identified in 1997 (15, 16), encompasses ten exons that encode a 610 amino acid protein referred to as menin $(17,18)$. Using polymorphic markers, loss of MEN1 locus was observed in $25-40 \%$ of sporadic parathyroid tumours, and an accompanying inactivating mutation was detected in about $50 \%$ of these tumours $(19,20,21)$.

The CCND1 gene (also known as PRAD1 - parathyroid adenomatosis 1) encodes a protein product that is a key regulator of the cell cycle. cCCND1 was first recognised as an oncogene in parathyroid tumours due its rearrangement with the PTH gene promoter region (22). Overexpression of this cell cycle regulator is observed in several human cancers such as breast, colon, lymphoma, melanoma and prostate (23). Cyclin D1 overexpression has been implicated through abnormal expression levels in the pathogenesis of $20-40 \%$ of sporadic parathyroid tumours $(24,25)$.

Regarding parathyroid carcinomas, inactivating mutations of parafibromin are the most common genetic events with a mutation rate ranging from 66 to $100 \%$ and concomitant loss of immunoreactivity. Consequently, it was advanced that parafibromin protein expression discriminates parathyroid carcinoma from benign parathyroid lesions (26).

The aim of this work is to perform a thorough molecular characterisation of a series of sporadic pHPT cases in order to contribute to a more accurate diagnosis and unveil pivotal steps in the etiopathogenesis.

\section{Materials and methods}

\section{Subjects}

A retrospective review of a database of patients with pHPT was conducted in Hospital Pedro Hispano (HPH), Portugal, retrieving 80 patients. Upon attainment of informed consent, 30 patients (8 males: 22 females; average age 61 years, ranging from 32 to 89 years) had a medical appointment consisting of a systematic interrogation about their personal, familial history and physical examination. The diagnosis of sporadic pHPT was based on elevated levels of serum calcium $(\geq 2.75 \mathrm{mmol} / \mathrm{l})$ and PTH ( $\geq 6.8 \mathrm{pmol} / \mathrm{l})$ and a negative family history. The study was approved by the ethics committee of $\mathrm{HPH}$, and all the procedures were in accordance with the institutional and national ethical rules.

\section{Genetic analysis}

Germline study of MEN1, RET and CDKN1B genes was performed in DNA extracted from peripheral blood leukocytes of 30 patients (27). The study of somatic alterations was carried out in DNA extracted (Puregene kit, Gentra Systems, Inc., Minneapolis, MN, USA) from formalin-fixed paraffin-embedded (FFPE) tissues from 24 patients, provided by the Department of Pathology of HPH (FFPE material from six patients was not available, not representative or degraded). The histological slides of the parathyroid lesions were reviewed by a pathologist (E F), with 19 tumours (79\%) classified as adenomas (uniglandular disease) and five (21\%) as hyperplastic glands (multiglandular disease).

\section{Mutational analysis}

The MEN1 (ENSG00000133895) gene coding exons 2-10, RET (ENSG00000165731) gene coding exons 10, 11 and 13-16 and the entire CDKN1B (ENSG00000111276) gene encoding exons 1 and 2 were amplified in the germline and somatic DNA samples by PCR, using specific primers and annealing temperatures (primers and annealing temperatures summarised in Supplementary Data: Tables 1 and 2). The PCR was performed in a volume of $25 \mu \mathrm{l}$ containing $5 \mu \mathrm{l}$ of $5 \times$ PCR buffer (Bioron, Ludwigshafen, Germany), $2.5 \mathrm{mM} \mathrm{MgCl}_{2}$ (Bioron), $1 \mu \mathrm{l}$ deoxynucleoside triphosphates ( $5 \mathrm{mmol} / \mathrm{l}$ each) (Bioron), $0.24 \mu \mathrm{M}$ of each primer, 1U Taq DNA Polymerase (Bioron) and 50100 ng genomic DNA. Thermal cycling conditions used were as follows: an initial denaturation step at $94{ }^{\circ} \mathrm{C}$ for $3 \mathrm{~min}$, followed by 35-40 cycles of denaturation at $94^{\circ} \mathrm{C}$ for $20 \mathrm{~s}$, annealing at $55-65^{\circ} \mathrm{C}$ for $30 \mathrm{~s}$, extension at $72{ }^{\circ} \mathrm{C}$ for $45 \mathrm{~s}$ and a final extension at $72{ }^{\circ} \mathrm{C}$ for $10 \mathrm{~min}$.

The samples were analysed by SSCP followed by direct DNA sequencing in the cases presenting abnormal electrophoresis mobility. SSCP was performed by denaturing samples and running them in a vertical 
electrophoresis using a Mutation Detection Enhancement (MDE) gel (Cambrex Bio Science Rockland, Inc., Rockland, ME, USA) at 8 or $20^{\circ} \mathrm{C}$ (exon dependent). Results were revealed using silver staining. PCR products were subjected to sequencing in both strands using the Big Dye Terminator Cycle Sequencing Reaction kit (Applied Biosystems, Life Technologies Corporation) and analysed on ABI PRISM 3100 Genetic Analyzer (Applied Biosystems). The CDKN1B exons and CTNNB1 exon 3 analysis was performed by PCR and direct sequencing as described elsewhere (28).

\section{Multiplex ligation-dependent probe amplification}

DNA from germline $(n=30)$ and tumour $(n=24)$ samples was analysed for genetic deletions using multiplex ligationdependent probe amplification (MLPA) kit (SALSA MLPA KIT P017-B1 MEN1 MRC Holland, Amsterdam, The Netherlands) according to the manufacturer's instructions. MLPA fragments were run on ABI PRISM 3100 Genetic Analyzer (Applied Biosystems), and the data were analysed using Coffalyser software (MRC Holland). MLPA results were reproduced at least three times.

\section{Molecular allelotyping}

Loss of heterozygosity ( $\mathrm{LOH})$ analysis was performed on DNA from tumour and matched peripheral leukocyte DNA. Three microsatellite markers at 11q13 (D11S956, PYGM and RH27780) region were used to evaluate the extension of MEN1 deletions provided by MLPA. In each primer pair, one nucleotide was labelled with TET or HEX. TAMRA500 (Applied Biosystems) was used as an internal size standard. In order to analyse allelic loss within the MEN1 locus, a polymorphism in exon 9 (SNP ID: rs2071313) was genotyped.

Fragment size analysis was performed using ABI PRISM 3100 Genetic Analyzer (Applied Biosystems). The data were analysed regarding allele size and quantitative information on allele height and area. $\mathrm{LOH}$ was defined according to the formula: $\mathrm{LOH}=(\mathrm{T} 2 \times$ $\mathrm{N} 1) /(\mathrm{T} 1 \times \mathrm{N} 2)$, where $\mathrm{T}$ was the tumour sample, $\mathrm{N}$ was the corresponding blood sample and 1 and 2 were the peak areas of smaller and larger alleles. $\mathrm{LOH}$ was defined with values of $\mathrm{LOH}$ index $<0.6$ or $>1.67$.

Microsatellite instability (MSI) was evaluated using five quasimonomorphic mononucleotide repeats named BAT-26, BAT-25, NR-24, NR-21 and NR-27 as described previously (29).

\section{Immunohistochemistry}

Sections of the parathyroid lesions were deparaffinised and rehydrated in alcohol. Endogenous peroxidase activity was quenched by incubating the slides with $3 \%(\mathrm{v} / \mathrm{v})$ hydrogen peroxide in methanol.
Microwave-treated antigen retrieval was used for cyclin D1, $\beta$-catenin, Ki-67 and p2 $7^{\text {Kip } 1}$ in $10 \mathrm{mM}$ citrate buffer, $\mathrm{pH}=6$, and EDTA buffer, $\mathrm{pH}=9$, for parafibromin protein. After blocking nonspecific staining (Ultra $\mathrm{V}$ Block, Thermo Fisher Scientific, Inc., Ottawa, ON, Canada), primary antibody was applied (cyclin D1 SP4, 1:100 (Neomarkers, Inc., Fremont, CA, USA); $\beta$-catenin, 1:4000 (c2206-1ML, Sigma-Aldrich); Ki-67 SP6, 1:200 (Neomarkers, Inc.); p2 ${ }^{\text {Kip1 }, ~ 1: 250 ~(C-19, ~}$ Santa Cruz Biotechnology, Inc.) and parafibromin, 1:50 (2H1, Santa Cruz Biotechnology)). Incubation with biotin-labelled secondary antibody (Biotinylated Goat Anti-Polivalent from Thermo Fisher Scientific, Inc.) was followed by revelation with 3,3-diaminobenzidine. The sections were counterstained with haematoxylin.

The anti-menin immunohistochemistry was performed with goat polyclonal antibody anti-menin (N-19 sc-8201; Santa Cruz Biotechnology). We used the Polink-2 Plus AP Goat Detection Kit (Golden Bridge International, Inc., Mukilteo, WA, USA) following the manufacturer's instructions. The immunohistochemical results were analysed according to the number of labelled cells, staining intensity, and protein subcellular location.

In all the experiments, positive and negative controls were used. The positive control was normal parathyroid tissue, except for cyclin D1 detection, where a breast cancer sample overexpressing this protein was used. The negative controls were performed by omission of the primary antibody.

\section{Statistical analysis}

In order to calculate the Hardy-Weinberg equilibrium, the Arlequin software (http://anthro.unige.ch/arlequin/) was used. Correlations were performed using Pearson correlation test, using SPSS 14.0 software. The level of statistical significance was set at $P<0.05$.

\section{Results \\ Study of germline mutations in MEN1, RET and CDKN1B genes}

A search for germline mutations in MEN1, RET and $C D K N 1 B$ genes was carried out. One patient had a germline heterozygous frameshift mutation (c.628_631delACAG) at exon 3 of the MEN1 gene and was thereby excluded from this study. None of the 30 cases showed large MEN1 germline deletions detected by MLPA and/or microsatellites polymorphic loci.

No other molecular alterations were detected at the germline level besides previously described, non-pathogenic DNA variants (Table 1). All the variants are in Hardy-Weinberg equilibrium and the genotypic and allelic frequencies found did not differ from those already described for European populations (http:// www.ncbi.nlm.nih.gov/snp). 
Table 1 Germline molecular alterations in MEN1, RET and CDKN1B genes $(n=30)$.

\begin{tabular}{|c|c|c|c|}
\hline Gene/exon & Genetic alteration classification & Nucleotide change & $\begin{array}{l}\text { Genotypic } \\
\text { frequencies (\%) }\end{array}$ \\
\hline MEN1/3 & Deletion & c.628_631delACAG ${ }^{a}$ & 0.03 \\
\hline MEN1/9 & Synonymous polymorphism & $\mathrm{GAC} \rightarrow \mathrm{GAT}(\mathrm{D} 418 \mathrm{D})$ & $\begin{array}{l}\mathrm{CC}=0.30 \\
\mathrm{CT}=0.57 \\
\mathrm{TT}=0.13\end{array}$ \\
\hline$R E T / 11$ & Non-synonymous polymorphism & $\mathrm{GGT} \rightarrow \mathrm{AGT}(\mathrm{G} 691 \mathrm{~S})$ & $\begin{array}{l}G G=0.80 \\
G A=0.17 \\
A A=0.03\end{array}$ \\
\hline$R E T / 13$ & Synonymous polymorphism & $\mathrm{CTT} \rightarrow \mathrm{CTG}(\mathrm{L769L})$ & $\begin{array}{l}\mathrm{TT}=0.40 \\
\mathrm{TG}=0.57 \\
\mathrm{GG}=0.03\end{array}$ \\
\hline RET/14 & Synonymous polymorphism & $\mathrm{AGC} \rightarrow \mathrm{AGT}(\mathrm{S} 836 \mathrm{~S})$ & $\begin{array}{l}\mathrm{CC}=0.90 \\
\mathrm{CT}=0.10\end{array}$ \\
\hline$C D K N 1 B / 1$ & Non-synonymous polymorphism & $\mathrm{GTC} \rightarrow \mathrm{GGC}(\mathrm{V} 109 \mathrm{G})$ & $\begin{array}{l}\mathrm{TT}=0.80 \\
\mathrm{TG}=0.17 \\
\mathrm{GG}=0.03\end{array}$ \\
\hline
\end{tabular}

${ }^{a}$ Mutation is numbered in relation to the MEN1 cDNA reference sequence (GenBank accession number NM_130799.1), whereby nucleotide +1 corresponds to the $A$ of the ATG - translation initiation codon.

\section{Somatic alterations in MEN1 gene}

Somatic mutations in the MEN1 gene were found in two of the 24 parathyroid tumours (two adenomas: cases 3 and 17, Fig. 3). The mutations were located in exon 2; a four base pair deletion (c.249_252delGTCT) previously described (16), and a new mutation corresponding to a 49 bp deletion (c.115_163del49bp). Both mutations are frameshift deletions resulting in altered amino acid sequences that create premature stop codons at positions 117 and 102 respectively, presumably leading to a truncated protein. None of the mutations were found in the corresponding leukocyte DNA and were therefore considered somatic mutations.

In case 17, harbouring the somatic c.115_163del49bp deletion, the electropherogram analysis indicated that the tumour cells were hemizygous for the mutant allele suggesting LOH of the normal allele. This result was further confirmed by MLPA analysis that pointed to loss of most of the MEN1 exons (Figs 1 and 3). As stated earlier, to exclude the presence of a germline deletion as the first hit (that could be missed by mutational analysis), the same methodology was applied to the corresponding leukocyte DNA. MLPA analysis of germline DNA did not show any sequence deletions, indicating that both events occur at the somatic level (Fig. 1).

Somatic intragenic deletions were further suspected in three additional cases (cases 1, 13 and 18), by analysis of the $\mathrm{D} 418 \mathrm{D}$ polymorphic marker localised in exon 9 of MEN1 gene. Those three patients, that present a heterozygous pattern $(\mathrm{C} / \mathrm{T})$ for the $\mathrm{D} 418 \mathrm{D}$ variant in the germline, presented a hemizygous profile in the tumour DNA. These observations together with the identification of a somatic intragenic deletion by MPLA in case 17 led to the analysis of all the remaining tumours for $\mathrm{LOH}$ using MLPA. MEN1 intragenic deletions were identified in seven additional cases, indicating the presence of $\mathrm{LOH}$ in $54 \%(13 / 24)$ of the parathyroid tumours analysed; nine $(69 \%)$ of these tumours were adenomas and the remaining four (31\%) hyperplastic glands. Despite the different extents of these deletions, and their spread throughout the gene, they compromise mainly the terminal portion of the gene, being exons 2 and 3 maintained in most cases (Fig. 3). Results for cases 16 and 19 were done only once due to the scarcity of biological material. The tumours were further analysed for $\mathrm{LOH}$ using three microsatellites polymorphic loci from chromosome 11q13. All tissues were informative for at least one polymorphic marker.

In order to discard the possibility of MSI in the cases, that could lead to $\mathrm{LOH}$ misinterpretation, a set of five well-established quasimonomorphic microsatellites loci (29) were amplified in the tumours' DNA and none of them showed signs of MSI at any of the microsatellite loci analysed. We did not verify any correlation between the molecular alterations previously described and the histopathology of the lesions.

\section{Genetic alterations in $\beta$-catenin and $27^{\text {Kip } 1}$}

DNA sequencing analysis did not reveal any mutation in exon 3 of CTNNB1 gene in the 24 studied tumours. The sequencing analysis of CDKN1B gene only revealed the presence of the variant already observed at the germline level, the V109G (SNP ID: rs2066827). The informative heterozygous genotypes in the germline were maintained at the somatic level, indicating retention of heterozygosity.

\section{Immunohistochemical study of menin, $\beta$-catenin, p2 $7^{\text {Kip } 1}$, cyclin D1, parafibromin and Ki-67}

MEN1 mutations and/or deletions in parathyroid tumours are likely to result in a reduced (or absent) 
A wild type MEN1

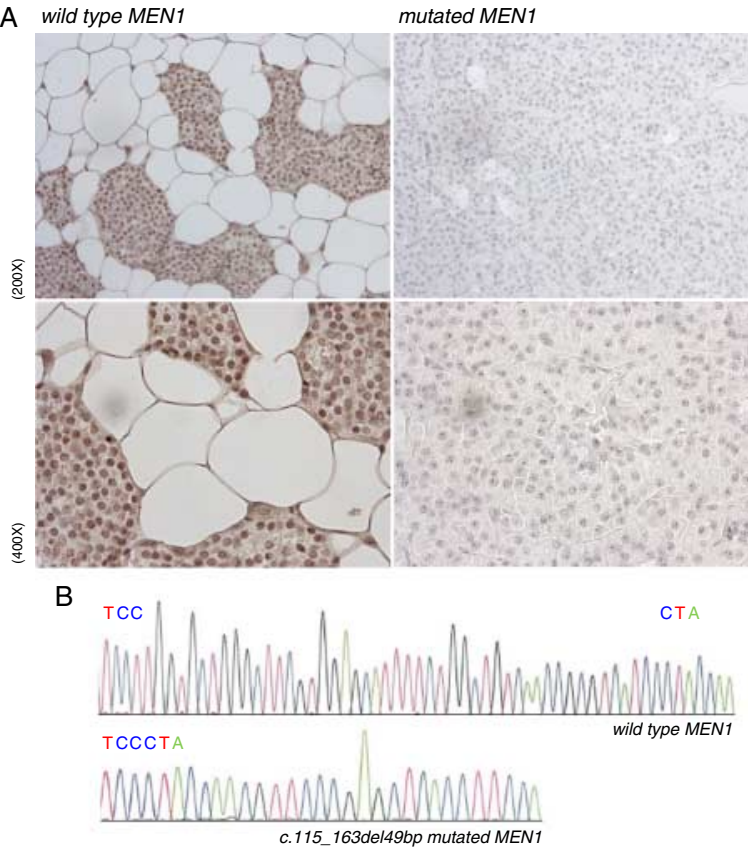

C
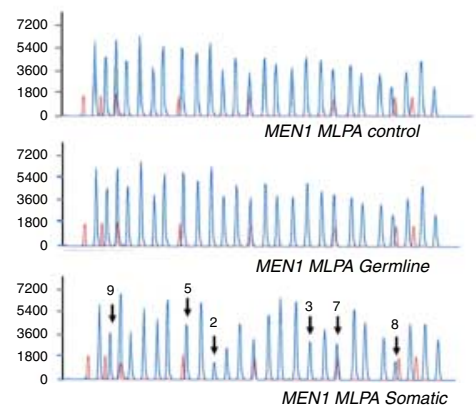

Figure 1 Somatic inactivation of both MEN1 alleles in case 17 leads to the absence of menin protein expression with consequent loss of immunoreactivity. As demonstrated in (A), using normal parathyroid tissue (wild type) as a reference, loss of menin expression was observed when compared with the tumour bearing MEN1 mutation (mutated MEN1). The images are in the original magnification $200 \times$ (upper images) and $400 \times$ (lower images); (B) MEN1 direct sequencing detected the presence of a deletion in the somatic counterpart (c.115_163del49bp mutated MEN1). The presence of the hemizygous deletion suggests inactivation of the other allele; (C) MLPA analysis confirmed the presence of a MEN1 large deletion at the somatic level, leading to the ablation of the second allele. Such loss was not observed in the respective germline and the control case. Black arrows point to the exons detected to be lost by the MLPA probes. Full colour version of this figure available via http://dx.doi.org/10.1530/EJE-12-0327.

expression of menin. Using an antibody against the $\mathrm{N}$-terminal region of the protein, nuclear and cytoplasmic immunoreactivity was detected in all except one parathyroid tumour, with a variable number of immunoreactive cells. However, compared with normal parathyroid tissue, the tumours evidenced a clear down-regulation of this protein (Fig. 3).

$\beta$-Catenin staining evidenced a clear membrane pattern in all the samples and the intensity of the staining ranged from weak to strong in 40-100\% of the tumour cells (Tables 2, 3 and Fig. 2). Nuclear localisation of the protein was not observed in any case. All tumour samples expressed nuclear p2 $7^{\text {Kip1 }}$ protein staining, ranging from 14 to $98 \%$ of positive tumour cells (Table 2 and Fig. 3).

In nine tumours, no cyclin D1 expression was detected, where the remaining 15 tumours showed positive expression of varying intensity. In three of the positive cases (two adenomas and one hyperplastic gland), nuclear overexpression (in 20-35\% of the tumour cells) was detected (Tables 2, 3 and Fig. 2).

In normal parathyroid tissue, parafibromin immunoreactivity displays a clear nuclear localisation. This staining pattern was maintained in all tumours that showed positivity in $70-100 \%$ of the tumour cells (Tables 2, 3 and Fig. 2). The 14 parathyroid tumours (12 adenomas and two hyperplastic glands) analysed for Ki-67 expression revealed low nuclear immunoreactivity (ranging from 0.02 to $4.2 \%$ ) (Tables 2 and 3 ). No correlation was found between immunostaining with any of the above-mentioned antibodies and the molecular alterations detected in the respective tumours.

\section{Discussion}

The most common form of presentation of pHPT is as a sporadic disorder caused by parathyroid adenoma and less frequently by hyperplasia and carcinoma, but the molecular alterations underlying the sporadic forms remain largely unknown (30). In this study, we verify
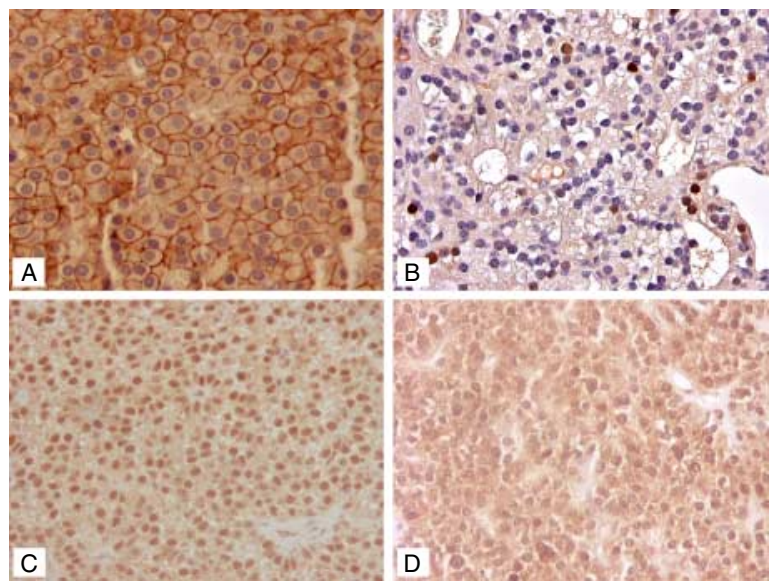

Figure 2 Representative areas of parathyroid tumours, exemplifying immunostaining for $\beta$-catenin, cyclin D1, parafibromin and p2 $7^{\text {Kip } 1}$ proteins. All images are presented with an original magnification of $400 \times$. From the immunohistochemistry results, we can observe: (A) $\beta$-catenin membranar immunostaining in $100 \%$ of the tumour cells; (B) overexpression of cyclin D1 protein in $20 \%$ of the parathyroid tumour cells; $(C)$ intense parafibromin staining in $100 \%$ of the tumour cells; and (D) expression of $227^{\mathrm{Kip} 1}$ protein in about $62 \%$ of the tumour cells. Full colour version of this figure available via http://dx.doi.org/10.1530/EJE-12-0327. 
Table 2 Evaluation of protein expression levels in the series of the parathyroid tumours.

\begin{tabular}{|c|c|c|c|}
\hline & $\begin{array}{l}\text { Positive } \\
\text { cases }\end{array}$ & $\begin{array}{l}\text { Stained } \\
\text { tumour } \\
\text { cells }(\%)\end{array}$ & $\begin{array}{l}\text { Protein } \\
\text { subcellular } \\
\text { location }\end{array}$ \\
\hline$\beta$-Catenin & $24 / 24$ & $40-100$ & Membranar \\
\hline p27 Kip1 & $24 / 24$ & $14-98$ & Nuclear and cytoplasmic \\
\hline Cyclin D1 & $15 / 24$ & $2-35$ & Nuclear \\
\hline Parafibromin & $24 / 24$ & $70-100$ & Nuclear \\
\hline Ki- 67 & $14 / 14$ & $0.02-4.2$ & Nuclear \\
\hline
\end{tabular}

that somatic intragenic deletions of MEN1 gene appear as the most frequent genetic event in sporadic pHPT.

In order to exclude the family origin of the parathyroid tumours in our series, a search for germline mutations in MEN1, RET and CDKN1B genes was carried out and none of the cases corresponded to MEN2 or MEN4 syndromes. Germline studies for other familial syndromes, like familial hypocalciuric hypercalcemia, neonatal severe HPT and HPT-JT, which can comprise pHPT as a clinical manifestation, were not performed due to the absence of familial and clinical data supporting such diagnoses.

The MEN1 molecular studies report several types of MEN1 mutations, which are scattered throughout the entire gene region. So far, neither hot spots have been described nor phenotype-genotype correlations have been established (31). About $40 \%$ of MEN1 mutations are frameshift due to small deletions or insertions (18). MEN1 large germline deletions compromise about 4\% of the genetic defects (32), and as it has been previously reported $(33,34)$, they are only detected using gene dose assays. Despite their role in MEN1 syndrome, mutations in this gene have also been identified in about $20 \%$ of familial isolated HPT cases $(35,36)$.

The D418D polymorphism detected in $70 \%$ of our series constitutes a relatively common polymorphism with no effects on protein (37). Correa et al. (38) demonstrated that MEN1 D418D was associated with pHPT, representing a genetic risk factor for the disease. Although we have not evaluated the frequency of the polymorphism in a control series, the allelic frequencies found for D418D in pHPT patients are similar to those described for European control populations (http:// www.ncbi.nlm.nih.gov/snp).

Two of the 24 tumours presented somatic mutations in MEN1 gene: a 4 bp (c.249_252delGTCT) deletion without LOH and the other a $49 \mathrm{bp}$ (c.115_163del49bp) deletion with loss of the wildtype allele. These frameshift mutations will lead either to truncated proteins with loss of functional domains, ablation of nuclear localisation signals in the C-terminal or result in loss of the translated protein due to nonsense-mediated mRNA decay (39). Additionally, it is known that both mutations occurred in a repetitive DNA sequence, consistent with a replication-slippage model of mutagenesis (18). In our series of parathyroid tumours, $8 \%$ of the cases presented somatic MEN1 mutations, which contrast with the $35 \%$ recently described by Newey et al. (40). At least two factors can explain these differences: on one hand, Newey et al. used whole-exome sequencing studies that can be much more sensitive, namely, detecting somatic mutations in heterogeneous tumours. On the other hand, the authors evaluated only uniglandular disease whereas $20 \%$ of our cases correspond to multiglandular disease (hyperplasia). The role of MEN1 mutations in these two entities remains to be fully comprehended.

The finding of the hemizygous 115_163del49bpmutated allele raised the hypothesis of a large germline deletion as the first hit that would have been missed by the conventional screening methods. The germline and somatic MLPA results enabled the exclusion of a germline large deletion, confirming the occurrence of the two inactivating events at the somatic level. These results were further confirmed with the microsatellite markers. The somatic biallelic inactivation detected seems to abolish menin expression as the immunostaining was lost in the tumour area (Fig. 1A), confirming the tumour suppressor role of MEN1 in parathyroid tumorigenesis.

Taking into consideration the results obtained, a question was raised concerning the extent of such MEN1 deletions in our series. Using MLPA assay both in germline and in somatic DNA, the presence of intragenic MEN1 somatic deletions in 54\% of the tumours was detected, pointing to MEN1 intragenic deletions as the most frequent event in sporadic pHPT tumours. Therefore, two challenging observations have drawn our attention: the presence of discontinuous MEN1 intragenic deletions and its possible role as a haploinsufficient gene in parathyroid tumorigenesis.

Gene deletions, either single-exon or partial/wholegene deletions, are reported for several tumour suppressors namely in colorectal (MLH1 and MSH2) (41), breast and ovarian cancers (BRCA1 and BRCA2) (42). Additionally, it is known that Alu repeats are associated with genetic rearrangements that can create opportunities for unequal homologous recombination that can occur at intrachromosomal level, leading to gain or loss of exons in a gene (43). The plausibility of this hypothesis regarding MEN1 gene was advanced by Fukuuchi et al. (44) that verify Alu repetitive elements scattered around MEN1 gene, suggesting a role for Alu sequences in MEN1 genetic deletions. Altogether, these data may support the discontinuity of MEN1 intragenic deletions found in our work. Although MLPA analysis represents a powerful tool in genetic analysis being used in numerous studies $(45,46)$, the confirmation of the observed intragenic deletions would require the subcloning of PCR products in plasmids and further sequencing. These experiments could not be performed due to scarcity of tumour tissue and large size of deletion, making it difficult to obtain a reliable PCR 


\begin{tabular}{|c|c|c|c|c|c|c|c|}
\hline Age & Pathology & D11S956 & PYGM & MLPA probes & RH27780 & Mutations & MEN1 IHC (extension / intensity) \\
\hline 76 & M & L & - & & $\square$ & & $54 \% /++$ \\
\hline 87 & M & - & - & & - & & $100 \% /+$ \\
\hline 77 & A & $\square$ & - & & - & c.249-252delGTCT & $72 \% /++$ \\
\hline 57 & A & $\square$ & $\square$ & | & - & & $100 \% /+$ \\
\hline 70 & A & $\square$ & $\square$ & & - & & $64 \% /++$ \\
\hline 61 & A & - & - & & $\square$ & & $28 \% /++$ \\
\hline 77 & A & $\square$ & $\square$ & & $\square$ & & $100 \% /++$ \\
\hline 54 & A & - & $\square$ & & - & & $62 \% /++$ \\
\hline 53 & A & - & - & & $\square$ & & $25 \% /++$ \\
\hline 32 & A & $\square$ & $\square$ & & - & & $32 \% /++$ \\
\hline 62 & A & $\square$ & - & & $\square$ & & $100 \% /++$ \\
\hline 47 & A & $\square$ & - & & $\square$ & & $40 \% /++$ \\
\hline 60 & M & $\square$ & $\square$ & & $\square$ & & $35 \% /+$ \\
\hline 46 & M & $\square$ & - & & $\square$ & & $100 \% /++$ \\
\hline 76 & A & $\square$ & - & & $\square$ & & ND \\
\hline 68 & A & $\square$ & $\square$ & & $\square$ & & $21 \% /++$ \\
\hline 58 & A & $\square$ & $\square$ & & - & c.115-163del49bp & $0 \% /-$ \\
\hline 82 & M & $\square$ & $\square$ & & - & & $61 \% /++$ \\
\hline 45 & A & $\square$ & - & & - & & $\mathrm{ND}$ \\
\hline 50 & A & $\square$ & $\square$ & & $\square$ & & $41 \% /++$ \\
\hline 72 & A & - & - & & $\square$ & & $29 \% /+$ \\
\hline 64 & A & - & $\square$ & & $\square$ & & $45 \% /++$ \\
\hline 62 & A & - & $\square$ & & - & & $100 \% /++$ \\
\hline 89 & A & $\square$ & - & & - & & $100 \% /++$ \\
\hline
\end{tabular}

Legend:

$\square$ Normal
$\square$ LOH with MLPA
${ }^{*}$ LOH with MLPA and LOH for D418D
Ambiguous MLPA
$-\quad$ Non-informative marker

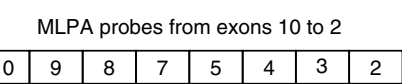

+ Analysis of MLPA was only performed once. $A$, adenoma; $M$, multiglandular hyperplasia; ND - not determined.

Figure 3 Data on allelic deletions, mutations and expression of MEN1 gene in the 24 parathyroid tumours.

product from FFPE. Also, the analysis by RT-PCR is not feasible, as RNA from the tumours is not available.

The other critical question is whether the observed MEN1 intragenic deletions compromise one or both alleles. As mentioned earlier, MLPA is a powerful tool but is not able to discriminate if the observed discontinuous exonic deletions involve only one or both alleles. The fact that MEN1 has been extensively described as a 'classical' tumour suppressor gene made us interpret our findings as intragenic biallelic inactivating deletions leading to protein down expression.
On the other hand, the hypothesis of monoallelic discontinuous intragenic deletions raises a critical question: the possibility that MEN1 haploinsufficiency can be enough for parathyroid tumours development, which, as far as we are aware, was never described in pHPT. However, the discontinuity data regarding MEN1 deletions presented in this study are preliminary and need further proof using independent methods.

The menin immunohistochemical results obtained in our work - all the cases, except one, evidence menin down expression compared with the only normal 
Table 3 Immunohistochemistry results for $\beta$-catenin, p27 Kip1 , cyclin D1, parafibromin, and Ki-67 proteins in the 24 parathyroid tumours.

\begin{tabular}{|c|c|c|c|c|c|c|c|c|c|c|c|c|c|c|}
\hline \multirow[b]{2}{*}{ Case } & \multicolumn{3}{|c|}{$\beta$-Catenin } & \multicolumn{3}{|c|}{ p22 ${ }^{\text {Kip1 }}$} & \multicolumn{3}{|c|}{ Cyclin D1 } & \multicolumn{3}{|c|}{ Parafibromin } & \multicolumn{2}{|c|}{$\mathrm{Ki}-67$} \\
\hline & $\%$ & Loc & Loc & $\%$ & Int & Loc & $\%$ & Int & Loc & $\%$ & Int & Loc & $\%$ & Loc \\
\hline 1 & 40 & ++ & M & 68 & ++ & $\mathrm{N} / \mathrm{C}$ & 2.7 & + & $\mathrm{N}$ & 75 & +++ & $\mathrm{N}$ & 0.02 & $\mathrm{~N}$ \\
\hline 2 & 100 & ++ & $M$ & 17 & + & C & 0.9 & + & $\mathrm{N}$ & 100 & +++ & $\mathrm{N} / \mathrm{C}$ & ND & - \\
\hline 3 & 100 & +++ & $M$ & 94 & + & $\mathrm{N} / \mathrm{C}$ & 0 & - & - & 100 & ++ & $\mathrm{N}$ & 1.0 & $\mathrm{~N}$ \\
\hline 4 & 100 & +++ & M & 30 & + & $\mathrm{N} / \mathrm{C}$ & 0.7 & ++ & $\mathrm{N}$ & 100 & ++ & $N$ & ND & - \\
\hline 5 & 100 & +++ & M & 32 & ++ & $\mathrm{N} / \mathrm{C}$ & 2.4 & +++ & $\mathrm{N}$ & 100 & +++ & $\mathrm{N}$ & 4.2 & $\mathrm{~N}$ \\
\hline 6 & 100 & +++ & $M$ & 50 & + & $\mathrm{N}$ & 0.7 & +++ & $\mathrm{N}$ & 100 & ++ & $\mathrm{N}$ & 3.8 & $\mathrm{~N}$ \\
\hline 7 & 100 & +++ & $M$ & 30 & ++ & $\mathrm{N} / \mathrm{C}$ & 19.7 & +++ & $\mathrm{N}$ & 100 & ++ & $\mathrm{N}$ & 1.1 & $\mathrm{~N}$ \\
\hline 8 & 70 & ++ & M & 70 & + & $\mathrm{N} / \mathrm{C}$ & 0.3 & +++ & $\mathrm{N}$ & 100 & ++ & $\mathrm{N}$ & ND & - \\
\hline 9 & 50 & ++ & $M$ & 17.7 & + & $N$ & 0.2 & + & $\mathrm{N}$ & 100 & ++ & $\mathrm{N}$ & 0 & - \\
\hline 10 & 80 & +++ & $M$ & 15.4 & ++ & $\mathrm{N}$ & 0.8 & ++ & $\mathrm{N}$ & 70 & +++ & $\mathrm{N}$ & 1.36 & $\mathrm{~N}$ \\
\hline 11 & 100 & +++ & $M$ & 40 & + & $\mathrm{N} / \mathrm{C}$ & 2.5 & +++ & $\mathrm{N}$ & 100 & +++ & $\mathrm{N}$ & 0 & - \\
\hline 12 & 100 & +++ & $M$ & 75.1 & +++ & $\mathrm{N}$ & 3.8 & ++ & $\mathrm{N}$ & 100 & ++ & $\mathrm{N}$ & ND & - \\
\hline 13 & 100 & +++ & M & 98.2 & + & $\mathrm{N}$ & 0.2 & ++ & $\mathrm{N}$ & 100 & +++ & $\mathrm{N}$ & ND & - \\
\hline 14 & 100 & +++ & $M$ & 60 & + & $\mathrm{N}$ & 16.5 & +++ & $\mathrm{N}$ & 100 & +++ & $\mathrm{N}$ & 0 & - \\
\hline 15 & 100 & +++ & $M$ & 72.9 & +++ & $\mathrm{N} / \mathrm{C}$ & 3.7 & ++ & $\mathrm{N}$ & 100 & +++ & $\mathrm{N}$ & ND & - \\
\hline 16 & 80 & +++ & $M$ & 14.2 & + & $\mathrm{N}$ & 1.1 & ++ & $\mathrm{N}$ & 80 & ++ & $\mathrm{N} / \mathrm{C}$ & 1.7 & $\mathrm{~N}$ \\
\hline 17 & 40 & ++ & M & 30 & ++ & $\mathrm{N} / \mathrm{C}$ & 1.79 & +++ & $\mathrm{N}$ & 100 & ++ & $\mathrm{N}$ & ND & - \\
\hline 18 & 100 & +++ & $M$ & 61.5 & ++ & $\mathrm{N} / \mathrm{C}$ & 2.9 & ++ & $\mathrm{N}$ & 100 & +++ & $\mathrm{N}$ & ND & - \\
\hline 19 & 60 & ++ & $M$ & 87.5 & +++ & $\mathrm{N} / \mathrm{C}$ & 35.3 & +++ & $\mathrm{N}$ & 100 & ++ & $\mathrm{N}$ & ND & - \\
\hline 20 & 70 & ++ & M & 18.5 & ++ & $\mathrm{N} / \mathrm{C}$ & 1.6 & ++ & $\mathrm{N}$ & 70 & ++ & $\mathrm{N} / \mathrm{C}$ & 3.8 & $\mathrm{~N}$ \\
\hline 21 & 100 & +++ & $M$ & 89.5 & +++ & $\mathrm{N} / \mathrm{C}$ & 2.2 & +++ & $\mathrm{N}$ & 100 & +++ & $\mathrm{N}$ & 1.4 & $\mathrm{~N}$ \\
\hline 22 & 100 & +++ & $M$ & 33 & ++ & $\mathrm{N}$ & 4.7 & ++ & $\mathrm{N}$ & 100 & +++ & $\mathrm{N}$ & 2.2 & $\mathrm{~N}$ \\
\hline 23 & 100 & ++ & $M$ & 88.5 & + & $\mathrm{N} / \mathrm{C}$ & 0.4 & + & $\mathrm{N}$ & 100 & +++ & $\mathrm{N}$ & ND & - \\
\hline 24 & 100 & +++ & $\mathrm{M}$ & 89.5 & ++ & $\mathrm{N} / \mathrm{C}$ & 0.2 & ++ & $\mathrm{N}$ & 100 & +++ & $\mathrm{N}$ & 1.5 & $\mathrm{~N}$ \\
\hline
\end{tabular}

$\%$, Percentage of stained cells; Int, intensity; Loc, localisation; M, membranar staining; N, nuclear staining; C, cytoplasmic staining; ND, not determined; + , weak; ++ , mild; +++ , strong.

parathyroid tissue available - are compatible with MEN1 inactivation. Our results are in agreement with Theodoropoulou et al.'s study where they verify MEN1 LOH accompanied by weak protein expression (47).

Although the immunohistochemical results for menin are in line with MLPA data, protein down expression was also observed in cases without any MEN1 genetic alterations. It is likely that additional mechanisms, independent of MEN1 mutations or LOH, may contribute to menin down-regulation in parathyroid tumours. Disruption of promoter activity, either by hypermethylation or by mutations of regulatory elements, is a common inactivating mechanism of tumour suppressor genes. Previous works demonstrate (48) that MEN1 promoter methylation can occur in pancreatic tumours, evidencing MEN1 as a methylation-prone tumour suppressor gene. The consequence of CpG island hypermethylation is down-regulation of gene expression and it has been shown to function as a second hit event that leads to biallelic inactivation in some tumour suppressor genes $(49,50,51,52)$. Methylation of genes involved in parathyroid tumorigenesis has not been extensively studied, and the role of MEN1 CpG hypermethylation remains to be clarified. Remarkably, Gao et al. (53) evidenced that MEN1 promoter hypermethylation is responsible for menin down expression in melanoma cells. The hypothesis that disruption of MEN1 promoter activity by mutation could constitute the 'second hit' in parathyroid tumours is plausible, but to our knowledge, the majority of the works developed so far did not reveal any divergence from the wild-type promoter sequence. Only Jager et al. (54) described the presence of a MEN1 regulatory mutation. These are important aspects to further elucidate the mechanism of MEN1 inactivation.

To our knowledge, this is the first report describing MEN1 intragenic deletions as a very frequent somatic event in parathyroid tumours in patients with sporadic pHPT. Further studies will be very relevant to verify the reproducibility of our findings and to analyse the biological effects of these intragenic deletions in pHPT.

\section{Declaration of interest}

The authors declare that there is no conflict of interest that could be perceived as prejudicing the impartiality of the research reported.

\section{Funding}

This study was supported by an IPG-UP Grant (IPG2007-32, with financial support from CGD) and by Portuguese Foundation for Science and Technology through project grant. IPATIMUP is an Associate Laboratory of the Portuguese Ministry of Science, Technology and Higher Education that is partially supported by the FCT.

\section{References}

1 Nilsson IL, Yin L, Lundgren E, Rastad J \& Ekbom A. Clinical presentation of primary hyperparathyroidism in Europe - nationwide cohort analysis on mortality from nonmalignant causes. Journal of Bone and Mineral Research 200217 (Suppl 2) N68-N74. 
2 Carlson D. Parathyroid pathology: hyperparathyroidism and parathyroid tumors. Archives of Pathology \& Laboratory Medicine 2010134 1639-1644.

3 Scarpelli D, D’Aloiso L, Arturi F, Scillitani A, Presta I, Bisceglia M, Cristofaro C, Russo D \& Filetti S. Novel somatic MEN1 gene alterations in sporadic primary hyperparathyroidism and correlation with clinical characteristics. Journal of Endocrinological Investigation 200427 1015-1021.

4 Dinnen JS, Greenwoood RH, Jones JH, Walker DA \& Williams ED. Parathyroid carcinoma in familial hyperparathyroidism. Journal of Clinical Pathology 197730 966-975. (doi:10.1136/jcp.30. 10.966)

5 Pellegata NS, Quintanilla-Martinez L, Siggelkow H, Samson E, Bink K, Hofler H, Fend F, Graw J \& Atkinson MJ. Germ-line mutations in p $27^{\mathrm{Kip} 1}$ cause a multiple endocrine neoplasia syndrome in rats and humans. PNAS 2006103 15558-15563. (doi:10.1073/pnas.0603877103)

6 Marinoni I \& Pellegata NS. p2 $7^{\mathrm{Kip} 1}$ : a new multiple endocrine neoplasia gene? Neuroendocrinology 201193 19-28. (doi:10. $1159 / 000320366$ )

7 Georgitsi M. MEN-4 and other multiple endocrine neoplasias due to cyclin-dependent kinase inhibitors (p27(Kip1) and p18(INK4C)) mutations. Best Practice \& Research. Clinical Endocrinology $\mathcal{E}$ Metabolism 2010 24 425-437. (doi:10.1016/j.beem.2010.01.001)

8 Malanga D, De Gisi S, Riccardi M, Scrima M, De Marco C, Robledo M \& Viglietto G. Functional characterization of a rare germline mutation in the gene encoding the cyclin-dependent kinase inhibitor p2 $7^{\text {Kip1 }}$ (CDKN1B) in a Spanish patient with multiple endocrine neoplasia-like phenotype. European Journal of Endocrinology 2012166 551-560. (doi:10.1530/EJE-11-0929)

9 Tahara H, Smith AP, Gaz RD \& Arnold A. Loss of chromosome arm 9p DNA and analysis of the p16 and p15 cyclin-dependent kinase inhibitor genes in human parathyroid adenomas. Journal of Clinical Endocrinology and Metabolism 199681 3663-3667. (doi:10.1210/jc.81.10.3663)

10 Kishikawa S, Shan L, Ogihara K, Utsunomiya H, Nakamura M, Nakamura Y, Naito A \& Kakudo K. Overexpression and genetic abnormality of p53 in parathyroid adenomas. Pathology International 199949 853-857. (doi:10.1046/j.1440-1827.1999. 00961.x)

11 Giles RH, van Es JH \& Clevers H. Caught up in a Wnt storm: Wnt signaling in cancer. Biochimica et Biophysica Acta 2003 1653 1-24. (doi:10.1016/S0304-419X(03)00005-2)

12 Polakis P. Wnt signaling and cancer. Genes and Development 2000 14 1837-1851. (doi:10.1101/gad.14.15.1837)

13 Bjorklund P, Akerstrom G \& Westin G. Accumulation of nonphosphorylated $\beta$-catenin and c-myc in primary and uremic secondary hyperparathyroid tumors. Journal of Clinical Endocrinology and Metabolism 200792 338-344. (doi:10.1210/ jc.2006-1197)

14 Ikeda S, Ishizaki Y, Shimizu Y, Fujimori M, Ojima Y, Okajima M, Sugino K \& Asahara T. Immunohistochemistry of cyclin D1 and $\beta$-catenin, and mutational analysis of exon 3 of $\beta$-catenin gene in parathyroid adenomas. International Journal of Oncology 200220 $463-466$

15 Chandrasekharappa SC, Guru SC, Manickam P, Olufemi SE, Collins FS, Emmert-Buck MR, Debelenko LV, Zhuang Z, Lubensky IA, Liotta LA et al. Positional cloning of the gene for multiple endocrine neoplasia-type 1. Science 1997276 404-407. (doi:10.1126/science.276.5311.404)

16 Lemmens I, Van de Ven WJ, Kas K, Zhang CX, Giraud S, Wautot V, Buisson N, De Witte K, Salandre J, Lenoir G et al. Identification of the multiple endocrine neoplasia type 1 (MEN1) gene. The European Consortium on MEN1. Human Molecular Genetics 1997 6 1177-1183. (doi:10.1093/hmg/6.7.1177)

17 Guru SC, Goldsmith PK, Burns AL, Marx SJ, Spiegel AM, Collins FS \& Chandrasekharappa SC. Menin, the product of the MEN1 gene. is a nuclear protein. PNAS 199895 1630-1634. (doi:10.1073/ pnas.95.4.1630)
18 Lemos MC \& Thakker RV. Multiple endocrine neoplasia type 1 (MEN1): analysis of 1336 mutations reported in the first decade following identification of the gene. Human Mutation 200829 22-32. (doi:10.1002/humu.20605)

19 Heppner C, Kester MB, Agarwal SK, Debelenko LV, EmmertBuck MR, Guru SC, Manickam P, Olufemi SE, Skarulis MC, Doppman JL et al. Somatic mutation of the MEN1 gene in parathyroid tumours. Nature Genetics $1997 \quad 16 \quad 375-378$. (doi:10.1038/ng0897-375)

20 Miedlich S, Krohn K, Lamesch P, Muller A \& Paschke R. Frequency of somatic MEN1 gene mutations in monoclonal parathyroid tumours of patients with primary hyperparathyroidism. European Journal of Endocrinology $2000 \mathbf{1 4 3}$ 47-54. (doi:10.1530/eje.0. 1430047)

21 Westin G, Bjorklund P \& Akerstrom G. Molecular genetics of parathyroid disease. World Journal of Surgery 200933 2224-2233. (doi:10.1007/s00268-009-0022-6)

22 Arnold A, Motokura T, Bloom T, Kronenberg H, Ruderman J, Juppner H \& Kim HG. The putative oncogene PRAD1 encodes a novel cyclin. Cold Spring Harbor Symposia on Quantitative Biology 199156 93-97. (doi:10.1101/SQB.1991.056.01.013)

23 Fu M, Wang C, Li Z, Sakamaki T \& Pestell RG. Minireview: cyclin D1: normal and abnormal functions. Endocrinology 2004145 5439-5447. (doi:10.1210/en.2004-0959)

24 Arnold A, Shattuck TM, Mallya SM, Krebs LJ, Costa J, Gallagher J, Wild Y \& Saucier K. Molecular pathogenesis of primary hyperparathyroidism. Journal of Bone and Mineral Research 2002 17 (Suppl 2) N30-N36.

25 Mallya SM \& Arnold A. Cyclin D1 in parathyroid disease. Frontiers in Bioscience 20005 D367-D371. (doi:10.2741/Mallya)

26 Howell VM, Haven CJ, Kahnoski K, Khoo SK, Petillo D, Chen J, Fleuren GJ, Robinson BG, Delbridge LW, Philips J et al. HRPT2 mutations are associated with malignancy in sporadic parathyroid tumours. Journal of Medical Genetics 200340 657-663. (doi:10.1136/jmg.40.9.657)

27 Miller SA, Dykes DD \& Polesky HF. A simple salting out procedure for extracting DNA from human nucleated cells. Nucleic Acids Research 198816 1215. (doi:10.1093/nar/16.3.1215)

28 Rocha AS, Soares P, Fonseca E, Cameselle-Teijeiro J, Oliveira MC \& Sobrinho-Simoes M. E-cadherin loss rather than $\beta$-catenin alterations is a common feature of poorly differentiated thyroid carcinomas. Histopathology $2003 \mathbf{4 2}$ 580-587. (doi:10.1046/ j.1365-2559.2003.01642.x)

29 Pedrazzani C, Corso G, Velho S, Leite M, Pascale V, Bettarini F, Marrelli D, Seruca R \& Roviello F. Evidence of tumor microsatellite instability in gastric cancer with familial aggregation. Familial Cancer 20098 215-220. (doi:10.1007/s10689-0089231-7)

30 Marx SJ. Hyperparathyroid and hypoparathyroid disorders. New England Journal of Medicine 2000343 1863-1875. (doi:10.1056/ NEJM200012213432508)

31 Tsukada T, Yamaguchi K \& Kameya T. The MEN1 gene and associated diseases: an update. Endocrine Pathology 200112 259-273. (doi:10.1385/EP:12:3:259)

32 Tham E, Grandell U, Lindgren E, Toss G, Skogseid B \& Nordenskjold M. Clinical testing for mutations in the MEN1 gene in Sweden: a report on 200 unrelated cases. Journal of Clinical Endocrinology and Metabolism 200792 3389-3395. (doi:10. 1210/jc.2007-0476)

33 Agarwal SK, Kester MB, Debelenko LV, Heppner C, EmmertBuck MR, Skarulis MC, Doppman JL, Kim YS, Lubensky IA, Zhuang $\mathrm{Z}$ et al. Germline mutations of the MEN1 gene in familial multiple endocrine neoplasia type 1 and related states. Human Molecular Genetics 19976 1169-1175. (doi:10.1093/ $\mathrm{hmg} / 6.7 .1169)$

34 Cavaco BM, Domingues R, Bacelar MC, Cardoso H, Barros L, Gomes L, Ruas MM, Agapito A, Garrao A, Pannett AA et al. Mutational analysis of Portuguese families with multiple endocrine neoplasia type 1 reveals large germline deletions. Clinical Endocrinology 200256 465-473. (doi:10.1046/j.13652265.2002.01505.x) 
35 Kassem M, Kruse TA, Wong FK, Larsson C \& Teh BT. Familial isolated hyperparathyroidism as a variant of multiple endocrine neoplasia type 1 in a large Danish pedigree. Journal of Clinical Endocrinology and Metabolism 200085 165-167. (doi:10.1210/ jc. 85.1.165)

36 Brandi ML, Gagel RF, Angeli A, Bilezikian JP, Beck-Peccoz P, Bordi C, Conte-Devolx B, Falchetti A, Gheri RG, Libroia A et al. Guidelines for diagnosis and therapy of MEN type 1 and type 2. Journal of Clinical Endocrinology and Metabolism 200186 5658-5671. (doi:10.1210/jc.86.12.5658)

37 Peppa M, Boutati E, Kamakari S, Pikounis V, Peros G, Koutsodontis G, Metaxa-Mariatou V, Economopoulos T, Raptis SA \& Hadjidakis D. Novel germline mutations of the MEN1 gene in Greek families with multiple endocrine neoplasia type 1. Clinical Endocrinology 2009 70 75-81. (doi:10.1111/j. 1365-2265.2008.03308.x)

38 Correa P, Lundgren E, Rastad J, Akerstrom G, Westin G \& Carling T. Multiple endocrine neoplasia type 1 polymorphism $\mathrm{D} 418 \mathrm{D}$ is associated with sporadic primary hyperparathyroidism. Surgery 2002132 450-455. (doi:10.1016/S0039-6060(02)00110-1)

39 Khajavi M, Inoue K \& Lupski JR. Nonsense-mediated mRNA decay modulates clinical outcome of genetic disease. European Journal of Human Genetics 200614 1074-1081. (doi:10.1038/sj.ejhg. 5201649)

40 Newey PJ, Nesbit MA, Rimmer AJ, Attar M, Head RT, Christie PT, Gorvin CM, Stechman M, Gregory L, Mihai R et al. Whole-exome sequencing studies of nonhereditary (sporadic) parathyroid adenomas. Journal of Clinical Endocrinology and Metabolism 2012 97 E1995-E2005. (doi:10.1210/jc.2012-2303)

41 Li L, McVety S, Younan R, Liang P, Du Sart D, Gordon PH, Hutter P, Hogervorst FB, Chong G \& Foulkes WD. Distinct patterns of germline deletions in MLH1 and MSH2: the implication of Alu repetitive element in the genetic etiology of Lynch syndrome (HNPCC). Human Mutation 200627 388. (doi:10.1002/humu.9417)

42 Agata S, Dalla Palma M, Callegaro M, Scaini MC, Menin C, Ghiotto C, Nicoletto O, Zavagno G, Chieco-Bianchi L, D’Andrea E et al. Large genomic deletions inactivate the BRCA2 gene in breast cancer families. Journal of Medical Genetics $2005 \mathbf{4 2}$ e64. (doi:10.1136/jmg.2005.032789)

43 Deininger PL \& Batzer MA. Alu repeats and human disease. Molecular Genetics and Metabolism $1999 \quad 67 \quad 183-193$. (doi:10.1006/mgme.1999.2864)

44 Fukuuchi A, Nagamura Y, Yaguchi H, Ohkura N, Obara T \& Tsukada T. A whole MEN1 gene deletion flanked by Alu repeats in a family with multiple endocrine neoplasia type 1 . Japanese Journal of Clinical Oncology 200636 739-744. (doi:10.1093/jjco/hyl089)

45 Erlandson A, Samuelsson L, Hagberg B, Kyllerman M, Vujic M \& Wahlstrom J. Multiplex ligation-dependent probe amplification (MLPA) detects large deletions in the MECP2 gene of Swedish Rett syndrome patients. Genetic Testing $2003 \quad 7$ 329-332. (doi:10.1089/109065703322783707)
46 Schwab CJ, Jones LR, Morrison H, Ryan SL, Yigittop H, Schouten JP \& Harrison CJ. Evaluation of multiplex ligationdependent probe amplification as a method for the detection of copy number abnormalities in B-cell precursor acute lymphoblastic leukemia. Genes, Chromosomes \& Cancer 201049 1104-1113. (doi:10.1002/gcc.20818)

47 Theodoropoulou M, Cavallari I, Barzon L, D'Agostino DM, Ferro T, Arzberger T, Grubler Y, Schaaf L, Losa M, Fallo F et al. Differential expression of menin in sporadic pituitary adenomas. Endocrine-Related Cancer 200411 333-344. (doi:10.1677/erc.0. 0110333)

48 Cavallari I, Silic-Benussi M, Rende F, Martines A, Fogar P, Basso D, Vella MD, Pedrazzoli S, Herman JG, Chieco-Bianchi L et al. Decreased expression and promoter methylation of the menin tumor suppressor in pancreatic ductal adenocarcinoma. Genes, Chromosomes $\mathcal{E}$ Cancer 200948 383-396. (doi:10.1002/gcc. 20650)

49 Herman JG, Latif F, Weng Y, Lerman MI, Zbar B, Liu S, Samid D, Duan DS, Gnarra JR, Linehan WM et al. Silencing of the VHL tumor-suppressor gene by DNA methylation in renal carcinoma. PNAS 199491 9700-9704. (doi:10.1073/pnas.91.21.9700)

50 Brauch H, Weirich G, Brieger J, Glavac D, Rodl H, Eichinger M, Feurer M, Weidt E, Puranakanitstha C, Neuhaus C et al. VHL alterations in human clear cell renal cell carcinoma: association with advanced tumor stage and a novel hot spot mutation. Cancer Research $2000601942-1948$.

51 Astuti D, Morris M, Krona C, Abel F, Gentle D, Martinsson T, Kogner P, Neumann HP, Voutilainen R, Eng C et al. Investigation of the role of SDHB inactivation in sporadic phaeochromocytoma and neuroblastoma. British Journal of Cancer 200491 1835-1841. (doi:10.1038/sj.bjc.6602202)

52 Schagdarsurengin U, Gimm O, Dralle H, Hoang-Vu C \& Dammann R. CpG island methylation of tumor-related promoters occurs preferentially in undifferentiated carcinoma. Thyroid 2006 16 633-642. (doi:10.1089/thy.2006.16.633)

53 Gao SB, Feng ZJ, Xu B, Chen Y, Zheng HH, Yin P, Hua X \& Jin GH. Menin represses malignant phenotypes of melanoma through regulating multiple pathways. Journal of Cellular and Molecular Medicine $2011 \quad 15$ 2353-2363. (doi:10.1111/j.1582-4934. 2010.01222.x)

54 Jager AC, Friis-Hansen L, Hansen TV, Eskildsen PC, Solling K, Knigge U, Hansen CP, Andersen PH, Brixen K, Feldt-Rasmussen U et al. Characteristics of the Danish families with multiple endocrine neoplasia type 1. Molecular and Cellular Endocrinology 2006249 123-132. (doi:10.1016/j.mce.2006.02.008)

Received 17 April 2012

Revised version received 3 October 2012

Accepted 23 October 2012 